ARTICLE

\title{
"Interactions with Purpose": Exploring Staff Understandings of Student Engagement in a University with an Ethos of Staff-Student Partnership
}

*Dr Abbi Flint, Freelance Educational Developer and Researcher, Abbi Flint Consulting, UK. Luke Millard, Director, Education Development Service, Birmingham City University, UK.

Contact: drabbiflint@hotmail.co.uk

ABSTRACT

This paper describes qualitative research that used concept-map mediated interviews to explore academic staff understandings of student engagement, within a UK university with an explicit ethos of student engagement through partnership. The research explored how staff conceptualised student engagement and how it was experienced through practice. Our findings indicate that understandings of student engagement are highly individual and contextual and were framed in diverse ways by our participants. However, there were features that cut across these diverse understandings. Reflecting on the difference between staff-student partnership and other forms of engagement, we suggest partnership can be distinguished by an understanding of engagement as a relationship between staff and students, and through the way features and values are put into practice.

KEYWORDS

engagement, partnership, definitions, values, staff

Student engagement is a high-profile topic in higher education (HE) policy, practice, and discourse. Despite its prevalence, the term student engagement is perceived by some as problematic and difficult to define (Macfarlane \& Tomlinson, 2017; Kahn, 2014; Vuori, 2014; Gibbs, 2016). In part, this is influenced by multiple drivers and motivations for student engagement. Within the UK, there are drivers from a policy perspective. For example, chapter B5 of the UK Quality Code for Higher Education (QAA, 2012) and the assessment criteria of the Teaching Excellence Framework (DfE, 2017). Pedagogic drivers draw on literature suggesting that engagement in "high-impact" educational activities will lead to better student retention, achievement, and outcomes (Kuh, 2008), and possibly enhance "the performance and 
reputation of the institution" (Trowler, 2010, p. 3). There are also individual drivers for staff, for whom the notion of engagement aligns with their political and/or pedagogic philosophy, often rooted in ideas of citizenship, empowerment, and emancipation (Healey, Flint, \& Harrington, 2014). It is perhaps not surprising that student engagement is defined in different ways by those with different rationales.

It is not possible, within this paper, to summarise the huge body of literature on student engagement; see, for example, P. Trowler and V. Trowler (2010), Wimpenny and Savin-Baden (2013) and, specifically relating to partnership, Mercer-Mapstone et al. (2017). A brief overview of relevant perspectives is included below to provide context for this study. Many authors follow Fredricks, Blumenfeld, and Paris' (2004) identification of the three dominant dimensions that define engagement:

Behavioural engagement draws on the idea of participation; it includes involvement in academic and social or extracurricular activities and is considered crucial for achieving positive academic outcomes and preventing drop-out. Emotional engagement encompasses positive and negative reactions to teachers, classmates, academic, and school and is presumed to create ties to an institution and influence willingness to do the work. Finally, cognitive engagement draws on the idea of investment; it incorporates thoughtfulness and willingness to exert the effort necessary to comprehend complex ideas and master difficult skills. (p. 60)

Kahu (2013) groups these dimensions within four research perspectives: behavioural; psychological (encompassing the cognitive, affective, and conative); socio-cultural; and holistic. In practice, the relationships between these dimensions are complex and blurred. For example, reflecting on the opportunities described in Kuh's (2008) "high-impact" practices, Bryson and Hardy (2012) note that many of these imply a level of investment and ownership by students (relating to the psychological dimension). However, others have pointed out that the relationship between behaviour and intellectual engagement is not clear, with the lack of visible behaviour not necessarily reflecting a lack of cognitive engagement (Gourlay, 2017; Fredricks et al., 2004). Some have framed dimensions of engagement as hierarchical, with behavioural engagement a baseline, followed by emotional and then cognitive engagement (Harris, 2008; Newbery, 2012).

A common framing of student engagement, drawn out by Solomonides, Reid, and Petocz (2012), is as a relational concept: “'Engagement' then is a term that has been widely used to describe various relationships between the student, study and the institution, including the campus" (p. 15-16). This requires us to ask with what (or whom) are students engaging? In different situations, this may be the course content, pedagogic activities, their professional identity, peers, academic and professional services staff, institutional processes and mechanisms, and the broader discipline/industry/profession.

Like the broader concept of student engagement, partnership is relational, but here the relationship is specifically with other people: with student peers, staff, and external partners. Student engagement through partnership in the context of learning and teaching can be framed 
as a process in which all parties invest in and derive mutual benefit from learning and/or working together (HEA, 2016). In partnership, students may share significant control and ownership of their learning, and there is a strong emphasis on notions of community and collaboration with others. In describing specific forms of staff-student partnerships, some authors use terms such as co-production (Neary, 2012), co-creation (Bovill, Cook-Sather, \& Felten, 2011), or co-inquiry (Werder \& Otis, 2010), whereas others use values-based definitions of partnership to describe these kinds of relationships (Healey, Flint, \& Harrington, 2014; Wenstone, 2012). In this paper, we position partnership as a specific form of student engagement. Where we refer to "student engagement," we are indicating the broader concept and where we use "partnership," this relates specifically to this form of engagement. Partnership is only one of many complementary forms of student engagement. Our focus on partnership does not diminish the importance of these other forms, and we recognise Gourlay's (2017) call to acknowledge that student engagement can be an internal as well as externally facing process.

There is a sense that the scholarly study of student engagement (and partnership) is maturing (Flint, 2016), moving from enthusiastic advocacy of student engagement as an unproblematic positive approach to a more critical analysis of the drivers, theoretical underpinnings, and (positive and negative) impacts of engagement activities. Drawing on Fielding (2004), we agree that part of establishing student engagement as a field of academic inquiry is "deconstructing the presumptions of the present" (p.296): unpicking the assumptions and perceptions that may influence the way that concepts like student engagement are interpreted in practice. The theoretical positions and models described above were developed by researchers and scholars immersed in this area of the scholarship of teaching and learning, and we are interested in how far these are shared and applied in practice. This research aims to contribute to this unpicking through exploring how student engagement is understood by academic staff within a university that has an explicit ethos of staff-student partnership.

\section{The institutional context}

Birmingham City University (BCU) is a UK university with twenty-four thousand students across four faculties. Its mission is focused around enabling students to access the creative and professional industries, and it has a multi-cultural student population that is heavily commuter based.

Since 2009, the university has run a Student Academic Partners (SAP) programme, which provides opportunities and incentive for students and staff to work in partnership on pedagogical initiatives to improve the student learning experience. A prerequisite for funding is the demonstration of partnership between staff and students, and the funding is only available to support payment of student hours.

At $\mathrm{BCU}$, over $70 \%$ of students live at home whilst they study, with similar numbers being employed alongside their studies. In this environment, enabling students to participate in partnerships is testing and led to the decision to pay students who participated in formal partnership work. Over fifteen hundred students have been employed, and five hundred staff members have participated in seven hundred funded projects over the past nine years. Projects 
tend to focus on the development of new content or resources, mentoring, employability, and the generation of community activities both within and outside the university.

The SAP programme was founded upon a desire to develop a culture of partnership. The institutional approach to student engagement "places the notion of students working with staff, as partners in the improvement of the learning experience, at the centre of our institutional enhancement agenda" (Nygaard, Brand, Bartholomew, \& Millard, 2013, p. 7).

This emphasises student partnership for a purpose beyond just partnership. The goal was for partnerships to improve the student learning experience of the many, not the few. The university could not address "a culture of partnership" by just engaging with fifty students. Those student partners needed to work with staff on projects that influenced the learning of the wider student body. The vision for SAP was to make it "applicable to the majority of students at the university, not just a minority." (Nygaard et al., 2013, p. 11).

The high profile of the SAP programme and the national recognition that followed was significant in that it became a recognised part of the university's core business, and it was celebrated in a student and staff collaborative publication: "Student Engagement: Identity, Motivation and Community" (Nygaard et al., 2013). In its strategic plan, the university stated that it wished to be recognised as a sector leader in student engagement. Working with students became part of the institutional dialogue at the university as funding opportunities and even new job adverts ask, "Where is the student in this?" Student participation and engagement in the very essence of the university was achieved and student engagement became a "state of mind" for staff.

When a way of behaviour is integrated as the norm within an organisation, you inevitably lose control of it. The managers of the SAP programme may have considered, in the early days, that all staff/student partnership activity happened within the SAP programme. However, once the vision was mainstreamed, this could now take place anywhere and be interpreted in different ways by both students and staff. Mainstreaming meant that some staff may not even know of the SAP programme, but would be carrying out a role or way of working with students that they saw elsewhere in the university and thought was the norm.

The SAP team speculated that staff may have been told by managers that they were required to engage in partnership activities with students, but that direction may have stopped there. The number of staff who participated in SAP projects over the past nine years was significant, but a considerable number of staff were undertaking work with students of which the SAP team knew little about. The question arose as to how the theme of partnerships was being interpreted by individuals and whether this really mattered, as long as partnershiprelated activities were happening. Through this research, we wanted to explore whether this institutional approach to student engagement was shared by staff and how it was interpreted and enacted in practice. In our context, the term "staff" is used to refer to employees of the university in academic, professional services, and management roles. The findings could help inform the future development of learning and teaching activities across the university, through a focused staff development offer (Curran \& Millard 2015), and it has the possibility of impacting on future institutional policy. 


\section{METHODOLOGY}

The research is a small-scale qualitative study comprising ten semi-structured interviews with academic staff. At the start of each interview, participants were asked to draw a concept map reflecting what student engagement meant to them in practice. In selecting this approach, we were inspired by research using concept maps to explore students' expectations and perceptions of their experiences (Kandiko \& Mawer, 2013). Using a "draw-and-talk" approach we gave participants time to silently create their concept map, then asked them to talk through this before beginning the interview questions. We intended for this approach to provide a participant-led focus to the interview, giving participants time to reflect on and express their views on student engagement in their own terms before interview questions began. Through engaging participants in discussion around their drawings, the process involved collaborative meaning-making and engaged participants in elements of the analysis (Mitchell, Theron, Stuart, Smith, \& Campbell, 2011). It also provided a complementary visual alternative to the narrative data collected at the interview, which we hoped would enable us to use participant-generated themes to inform the analysis (Wheeldon \& Faubert, 2009; Kinchin, Streatfield \& Hay, 2010). The interview questions focused on participants' understanding of student engagement, examples they thought represented good practice in student engagement and excellent teaching, and their thoughts on responsibility and community in relation to student engagement.

Given the small number of participants, the intention was not to represent the views of all academic staff but to explore diverse individual perceptions and experiences of student engagement in practice. The sample included academic staff (with different levels of seniority) from subject areas in all four faculties of the university and the educational development unit and comprised five women and five men. Five participants had previously participated in SAP projects. Whilst we recognised that many staff within the institution play important and active roles in student engagement, we deliberately focused on academic staff, as we felt this group often has significant learning- and teaching-related interactions with students.

The two authors shared the interviewing, with some conducted jointly, and all interviews were recorded and transcribed. Coding and analysis were undertaken by the lead author, informed by a phenomenological perspective (Cohen, Manion, \& Morrison, 2011). Close reading of transcripts led to the development of codes grounded in participants' experiences and perspectives. Summaries of the way engagement was framed were produced for each participant's transcript and concept map. Codes were clustered into categories and used to explore themes across the data. The analysis was exploratory, focused on understanding how participants made sense of engagement and applied their understandings in practice. The analysis of the concept maps drew on social semiotics (Kress \& van Leeuwen, 1996; Jewitt \& Oyama, 2001). As part of the analysis, the lead author reflected on how participant understandings of student engagement related to framings from the literature and how participants described the role of different parties (i.e., staff and students).

The data were rich and wide ranging, and it is not possible to represent this comprehensively within the scope of this paper. In the following section, we focus on participants' conceptualisations of student engagement.

Flint, A., \& Millard, L. (2018). "Interactions with purpose": Exploring staff understandings of student 25 engagement in a university with an ethos of staff-student partnership. International Journal for Students as Partners, 2(2). https://doi.org/10.15173/ijsap.v2i2.3410 


\section{FINDINGS}

\section{Student engagement as complex and multi-dimensional}

The complexity and variability of understandings of student engagement were reflected in participants' drawings, how they talked through these, and their responses to interview questions. Some participants found student engagement difficult to define, and their understandings emergent: "I think part of the problem with engagement is it's an incredibly nebulous word." (Participant 3); "It's evolved somewhat organically." (Participant 8)

\section{Framings of student engagement}

Participants' drawings were all classificatory structures, representing the concept of student engagement and its component parts or attributes. They were top-down, placing the viewer in a privileged perspective described as 'orientated towards 'theoretical,' objective knowledge" (Kress \& van Leeuwen, 1996, p. 149). This is perhaps unsurprising, given participants were asked to represent a theoretical concept. However, structures and framings varied considerably. Although we prompted participants to create a concept map, only one drew this kind of diagram. Others created mind maps, Venn diagrams, and boxed and circular structures. These structures enabled alternative ways of viewing how participants framed student engagement and exploring the multiple dimensions that made up their understandings. For some, this reflected the locus of engagement: one diagram articulated this as relating to scale (university, community, course, and self); another described a pedagogic framing located within the classroom, with engagement linking theory and practice- "where the two worlds meet." (Concept map, participant 5)

Others contextualised their framing of student engagement in the student life cycle (with areas of the diagram reflecting transitions into, during, and out of university) or as influenced by different factors (external environment, attitudes, and institutional processes). Two diagrams reflected a conceptual framing for student engagement; one as a form of student voice, another as collaboration. Finally, some diagrams reflected different stakeholder perspectives, focusing on their individual staff role or distinguishing between their perspective and those of management and students.

Participants explored their understandings more deeply in the verbal part of the interview, with themes emerging around student engagement as (1) a relationship between staff and students, (2) student development and growth, and (3) a holistic concept.

\section{Student engagement as a relationship between staff and students}

The framing of student engagement as a relationship focuses on interpersonal dimensions, describing engagement as about "people not systems" (Participant 4). Participants spoke of the importance of sharing time and space together through collaborative projects and informal social engagement to make personal connections and enable relationships to grow organically.

There's quite a lot of engagement, which is just informal. That's just social conversations. We haven't got a water cooler, but if we did, that will be those kind of 
conversations [...] That sort of social element, social conversations, I think is key to making the students feel like they're engaged. (Participant 7)

However, these were framed as professional relationships and some participants were very clear where the boundaries were. For example, one described how they may go for lunch with a group of students but not for a night out. Another made it clear that they would not connect with students on social media whilst they had a teacher-student relationship but said it was fine for students to connect with them after graduation if they wanted to.

It's all about relationships. When the students come through the doors we need to build strong professional bonds, relationships with them, live those kind of principles [...] I think if you can get the relationships right, then you're halfway there in terms of student engagement. (Participant 6)

\section{Student engagement as a process of student development and growth}

For some participants, the framing of engagement as a developmental process for students was goal oriented-to support students to achieve their academic and professional goals, and develop social capital. Others described a more general concept, reflecting the transformative potential of education:

It's about trying to find ways that students can grow. (Participant 1) Ultimately, it is about growth and development, isn't it? You do a degree, you go into higher education, it ought to be a transformatory experience. You should come out a different person to the one you went in. (Participant 6)

\section{Student engagement as a holistic experience}

Participants who spoke about the holistic nature of student engagement described multiple aspects, but a common thread was student engagement as "more than ..." For some, this was about students seeing their own engagement as more than taking assignments or getting a degree. This also related to the locus of engagement, as some participants spoke about it being more than engaging in the course and encompassing extracurricular activities. The nature and impact of engagement in these different loci was perceived as interconnected and complex.

[For] the students to engage academically and professionally, personally, pastorally, whatever we're offering, engagement exists on lots of different levels, and they're all...I think it would be quite hard [...] to pick and unravel where engagement in perhaps extracurricular activities, has helped them academically [...] but all of it is about engagement. (Participant 8) 
A holistic framing was also implied in descriptions of engagement involving collaboration across all areas and services of the university and within the context of a wider culture or ethos of engagement.

\section{Features of student engagement}

Throughout the interviews, many participants highlighted specific features of student engagement; some of these related to the attitude of and approaches taken by staff and students; others were more akin to values or principles applied to practice and behaviour. Table 1 presents the main themes of (1) features relating to students, (2) approaches used by staff, and (3) features which apply to students and staff.

Table 1. Themes relating to features of student engagement

\begin{tabular}{|c|c|c|c|}
\hline $\begin{array}{l}\text { WHO THE } \\
\text { FEATURE } \\
\text { APPLIED TO }\end{array}$ & THEME & DETAILS & ILLUSTRATIVE QUOTES \\
\hline \multirow[t]{4}{*}{ Students } & Ownership & $\begin{array}{l}\text { Students taking ownership of } \\
\text { elements of learning and } \\
\text { assessment activities and } \\
\text { outcomes as part of the } \\
\text { course or extracurricular } \\
\text { activities. }\end{array}$ & $\begin{array}{l}\text { So the only barrier was their } \\
\text { own creativity and the } \\
\text { initiative. And they took it, } \\
\text { they ran with it, and they } \\
\text { created some very interesting } \\
\text { campaigns as a result. } \\
\text { (Participant 5) }\end{array}$ \\
\hline & Investment & $\begin{array}{l}\text { Students working hard and } \\
\text { being motivated. }\end{array}$ & $\begin{array}{l}\text { They've done loads of work, } \\
\text { and I think that's } \\
\text { engagement. (Participant 3) }\end{array}$ \\
\hline & Participation & $\begin{array}{l}\text { Students attending taught } \\
\text { sessions, being present on } \\
\text { campus, and taking part in } \\
\text { and contributing to learning } \\
\text { activities (e.g., through asking } \\
\text { questions, sharing opinions, } \\
\text { and challenging ideas). }\end{array}$ & $\begin{array}{l}\text { One is turning up. Two is } \\
\text { turning up and listening. And } \\
\text { three would be turning up, } \\
\text { listening, and taking part in } \\
\text { the activities [...] And I'll say } \\
\text { the top level one would be, } \\
\text { you're taking a lead in those } \\
\text { sort of group activities. } \\
\text { (Participant 7) }\end{array}$ \\
\hline & $\begin{array}{l}\text { Reflection and } \\
\text { self-knowledge }\end{array}$ & $\begin{array}{l}\text { Students reflecting and } \\
\text { developing awareness of } \\
\text { themselves. }\end{array}$ & $\begin{array}{l}\text { Your willingness to face up to } \\
\text { your own shortcomings and } \\
\text { to have the confidence to } \\
\text { take that on the chin and see } \\
\text { that as actually a signpost of } \\
\text { things you can kind of } \\
\text { develop and to actually } \\
\text { engage with enthusiasm with }\end{array}$ \\
\hline
\end{tabular}




\begin{tabular}{|c|c|c|c|}
\hline & & & $\begin{array}{l}\text { that kind of growth. } \\
\text { (Participant 6) }\end{array}$ \\
\hline \multirow[t]{4}{*}{$\begin{array}{l}\text { Staff (and } \\
\text { approaches } \\
\text { to teaching) }\end{array}$} & $\begin{array}{l}\text { Relevant and } \\
\text { authentic } \\
\text { learning } \\
\text { experiences }\end{array}$ & $\begin{array}{l}\text { Enabling students to make } \\
\text { connections to their personal, } \\
\text { learning, and professional } \\
\text { goals, through making } \\
\text { content and learning relevant } \\
\text { to assessment tasks and long- } \\
\text { term aspirations. Examples } \\
\text { included "live" project briefs, } \\
\text { experiential learning and field } \\
\text { work, testing ideas in } \\
\text { practice, and professional } \\
\text { development. }\end{array}$ & $\begin{array}{l}\text { The first one is getting an } \\
\text { external client to give you a } \\
\text { brief. The nice thing about } \\
\text { that is [...] it makes the } \\
\text { students feel, "Oh, great. } \\
\text { We're doing something for } \\
\text { [company name]." Ups the } \\
\text { sort of awesomeness of the } \\
\text { work. It feels less like I'm } \\
\text { doing a university assignment } \\
\text { and more like I'm doing some } \\
\text { work for [company name]. } \\
\text { (Participant 7) }\end{array}$ \\
\hline & $\begin{array}{l}\text { Setting clear } \\
\text { expectations of } \\
\text { students }\end{array}$ & $\begin{array}{l}\text { Shaping student expectations } \\
\text { of what university is like, how } \\
\text { they will learn, and the } \\
\text { parameters for their } \\
\text { engagement. Communicating } \\
\text { high expectations of student } \\
\text { achievement. }\end{array}$ & $\begin{array}{l}\text { I think sometimes, it ought to } \\
\text { be challenging, but I think we } \\
\text { should be explicit about it } \\
\text { and supportive of students, } \\
\text { so we should be upfront and } \\
\text { say to students, "This is going } \\
\text { to challenge you." } \\
\text { (Participant 6) }\end{array}$ \\
\hline & $\begin{array}{l}\text { Fostering } \\
\text { collaboration }\end{array}$ & $\begin{array}{l}\text { Encouraging student } \\
\text { collaboration through } \\
\text { teaching and extra-curricular } \\
\text { activities (e.g., group work, } \\
\text { team projects). Staff-student } \\
\text { collaborations and co- } \\
\text { creation through social and } \\
\text { extracurricular activities and } \\
\text { learning and teaching } \\
\text { enhancement projects. }\end{array}$ & $\begin{array}{l}\text { Integrated assessments not } \\
\text { just across the years, but } \\
\text { getting some of our final-year } \\
\text { students to do things with } \\
\text { the first-year students. } \\
\text { (Participant 1) }\end{array}$ \\
\hline & Flexibility & $\begin{array}{l}\text { Tailoring approaches to } \\
\text { teaching and wider } \\
\text { engagement to context, } \\
\text { taking into consideration the } \\
\text { diversity of the student body, } \\
\text { the needs and wants of } \\
\text { individual students, different } \\
\text { levels of engagement, and } \\
\text { disciplinary cultures. This may }\end{array}$ & $\begin{array}{l}\text { Best practice in student } \\
\text { engagement will be anything } \\
\text { that allows for individual } \\
\text { needs, anything that allows } \\
\text { for individuality of students, I } \\
\text { would suggest. (Participant } \\
\text { 10) }\end{array}$ \\
\hline
\end{tabular}




\begin{tabular}{|c|c|c|c|}
\hline & & $\begin{array}{l}\text { involve creating space for } \\
\text { student choice, creative } \\
\text { freedom, and personalisation. }\end{array}$ & \\
\hline & Recognition & $\begin{array}{l}\text { Acknowledging and } \\
\text { celebrating students' } \\
\text { achievements. }\end{array}$ & $\begin{array}{l}\text { We should say that we expect } \\
\text { great things of you because } \\
\text { we know you can achieve } \\
\text { them; our students go on to } \\
\text { do wonderful things and we } \\
\text { should celebrate that much, } \\
\text { much more. (Participant } 8 \text { ) }\end{array}$ \\
\hline & $\begin{array}{l}\text { Fostering } \\
\text { inclusivity }\end{array}$ & $\begin{array}{l}\text { Ensuring opportunities are } \\
\text { open and accessible to all } \\
\text { (considering scale and } \\
\text { diversity) and recognising the } \\
\text { importance of being invited. }\end{array}$ & $\begin{array}{l}\text { I don't think it should be } \\
\text { isolated to just kind of a key } \\
\text { few students who are } \\
\text { engaged. I think it should be } \\
\text { broadened out as far as } \\
\text { possible to other students } \\
\text { because some of the weaker } \\
\text { students are the ones who } \\
\text { need it the most. (Participant } \\
\text { 2) }\end{array}$ \\
\hline \multirow[t]{3}{*}{$\begin{array}{l}\text { Staff and } \\
\text { students }\end{array}$} & Community & $\begin{array}{l}\text { Developing a sense of } \\
\text { belonging and community. } \\
\text { This might operate at the } \\
\text { student group, discipline, } \\
\text { institutional, HE, or wider } \\
\text { societal level. Some framed } \\
\text { this as a learning or academic } \\
\text { community. }\end{array}$ & $\begin{array}{l}\text { We should see the university } \\
\text { and the schools and however } \\
\text { you want to do it we should } \\
\text { see it as a community and } \\
\text { we're all there for everyone } \\
\text { to do well. So engagement } \\
\text { just has to be everywhere. } \\
\text { (Participant 10) }\end{array}$ \\
\hline & $\begin{array}{l}\text { Dialogue and } \\
\text { interaction }\end{array}$ & $\begin{array}{l}\text { Two-way conversations with } \\
\text { students, which can take } \\
\text { place in class, through formal } \\
\text { mechanisms (like forums), } \\
\text { and through informal and } \\
\text { social interactions. These } \\
\text { varied in scale and form (e.g., } \\
\text { group and one-to-one). }\end{array}$ & $\begin{array}{l}\text { So the student engagement } \\
\text { for me has been about that } \\
\text { central dialogue and } \\
\text { communication not just } \\
\text { between me as the academic } \\
\text { and them, but between the } \\
\text { students themselves and how } \\
\text { that fits into the broader } \\
\text { institution. (Participant 2) }\end{array}$ \\
\hline & Communication & $\begin{array}{l}\text { Communication was central } \\
\text { to staff-student relationships } \\
\text { and dialogue. More broadly, } \\
\text { this included student voice } \\
\text { activities, staff }\end{array}$ & $\begin{array}{l}\text { Student voice is clearly an } \\
\text { important thing. So asking } \\
\text { students and talking with } \\
\text { students and trying to } \\
\text { understand what it is that }\end{array}$ \\
\hline
\end{tabular}




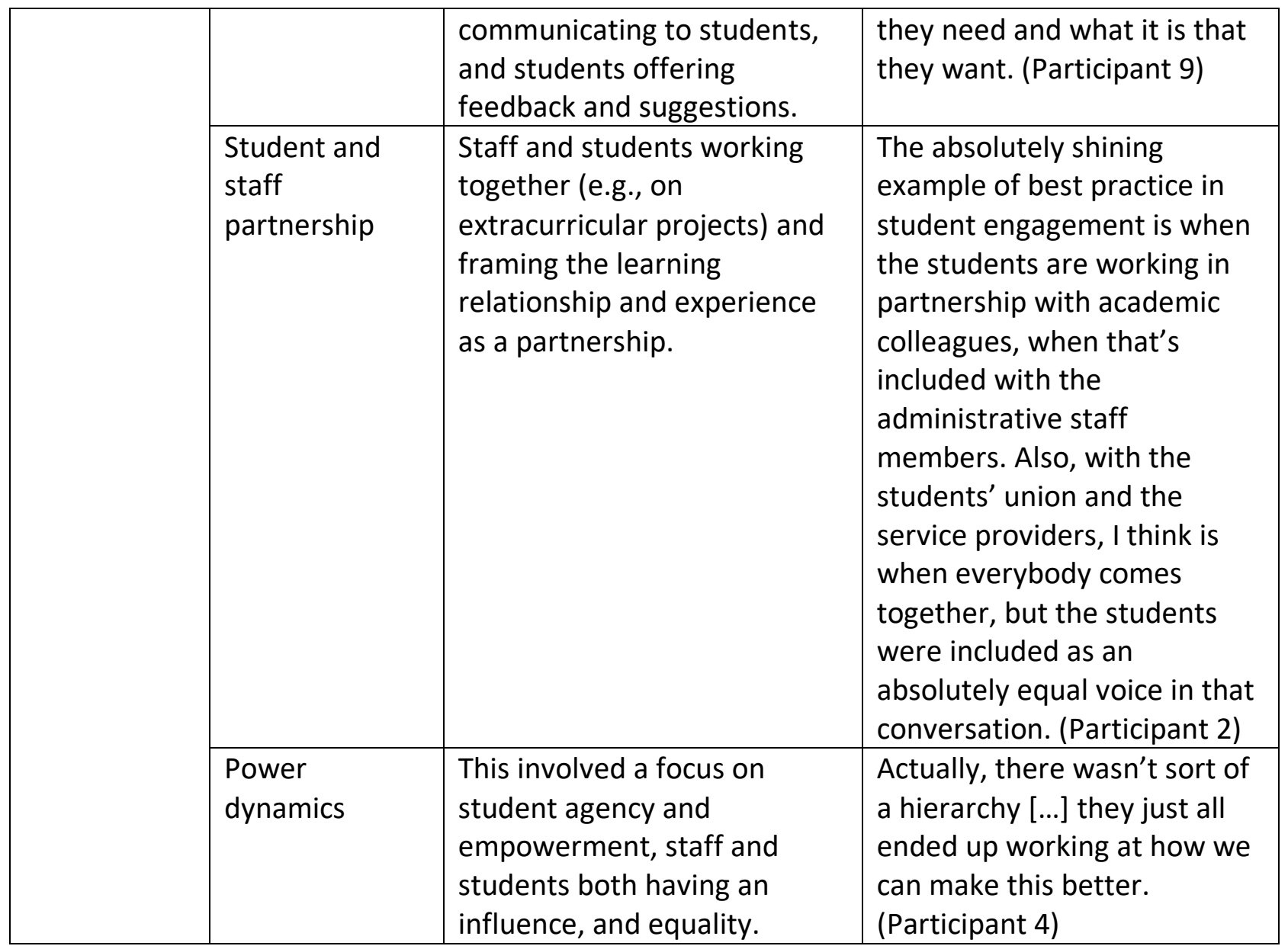

Other features which related to both staff and students included being open to risk and being proactive. Participants also described values that built relationships (such as honesty, trust, and rapport), and the idea of a shared student and staff experience (mutual learning and shared responsibility, knowledge, interests, and identity).

\section{Desired student attitudes and behaviours}

Many participants described attitudes and behaviours that defined engaged students. These included students investing in and taking responsibility for their learning, being proactive and active, being lifelong learners, being intrinsically motivated, embracing challenge and plurality, having intra- and inter-personal intelligence, and being reflective, professional, and articulate. Positive emotional dispositions associated with engaged students included enthusiasm, excitement, and passion. There is perhaps a normative aspect to this, articulating acceptable and expected behaviours and qualities of engaged students.

I'm trying to think of students that I would consider to be engaged. They are proud of their institution; they take part in things. They tend to attend, actually. You see them around the place, they are...they like the social part of it, they don't necessarily distinguish between work and leisure, they want to be here, they're here at open days, 
they're here at applicant visit days, they are proud of us. And then, they're articulate, they will come and talk to people if things aren't exactly going right. They want to make it better, they usually have a narrative which is, "I'm coming to tell you because I think you should know this, or we could do this." They have ideas, and they just want to get to the right place, so they can be helped with those ideas. (Participant 3)

\section{Staff role in student engagement}

Many participants described their role in student engagement as facilitative: encouraging and enabling students to engage; advising and guiding students; setting parameters; and creating a culture that fosters engagement. Some described their role as leading, being a role model and supporting colleagues to develop engaging approaches. Others saw their role as to push students and challenge institutional practices that inhibited engagement. In some cases, the level of student ownership was described as controlled by staff, who created the opportunities for, and boundaries of, this: "we gave them all that structure but enough space that they can have their own stamp on it." (Participant 7)

Many participants referred to their own attitudes or the attitudes of colleagues that enabled engagement in practice. These included being curious and reflective in relation to their practice and how students experienced learning; being enthusiastic about their subject; being approachable, supportive, and responsive; demonstrating care for students and a desire for them to succeed; being creative and willing to try out new ideas and take risks; going over and above what was expected of their role; treating students with respect and professionalism; and seeing students as on an equal footing.

\section{DISCUSSION}

The conceptual models of student engagement held by our participants were varied: some were emergent and previously unarticulated, whilst others were clearly framed by core ideas and elements. Participants understood student engagement as multi-dimensional. In many cases, this aligned with the cognitive (investment, ownership, reflection, and selfknowledge), behavioural (participation, collaboration, and interaction) and affective (community, student, and staff attitudes) dimensions described by Fredricks et al. (2004), Kahu (2013), and Kahu, Picton, and Nelson (2017). The developmental framing of engagement (with its focus on confidence, voice, and enabling students to recognise and fulfil their potential) combined with cognitive dimensions, has much in common with ideas of self-authorship-"the internal capacity to define one's belief system, identity, and relationships" (Baxter Magolda, 2007, p. 69; Hodge, Baxter Magolda, \& Haynes, 2009). Whilst participants drew on different framings, no participants held uni-dimensional views. Individual conceptualisations comprised plural (potentially dissonant) elements: student engagement could simultaneously involve elements of student voice and partnership despite these being qualitatively different forms of engagement. This concurs with Newbery's (2012) assertion that people hold multiple models at once and that "student engagement is not an either-or phenomenon, but rather a matter of degree" (p. 54). For us, this emphasises the importance of taking a situated and flexible 
approach to student engagement, recognising that its exact nature may vary in different settings.

Student engagement as a relationship between staff and students emerged as a theme in our data and was reflected in the emphasis on interpersonal or relational features (e.g., community, partnership, collaboration, dialogue, and effective communication). Given that staff-student partnership describes a specific form of student-staff relationship, we suggest that understanding student engagement as a relationship between staff and students is a prerequisite for partnership. This raises the question: What distinguishes partnership from other forms of engaging relationships?

The features of student engagement described by our participants share common elements with published partnership principles. For example, Cook-Sather, Bovill, and Felten (2014) list respect, reciprocity, and responsibility as three guiding principles for partnership. When asked who they felt was responsible for student engagement, many participants articulated this as a shared staff-student responsibility. Respect and reciprocity were less emphasised. However, when discussing the potential benefits of student engagement, participants outlined these in terms of benefits to staff, students, and the institution, suggesting student engagement was mutually beneficial for all parties. The Higher Education Academy (HEA) outlines nine partnership values (2016): authenticity; trust; honesty; courage; inclusivity; plurality; reciprocity; empowerment; and responsibility. Comparing these with the features described in Table 1, we recognise areas of overlap. Chickering and Reisser (1993) proposed that "colleges should foster (student) development by providing an empowering balance of challenge and support. Too much challenge could be overwhelming, but too much support created a static comfort zone" (p. 1). We argue that in the context of relational models of student engagement, such relationships should facilitate the challenge and support aspects to be balanced to enable student development.

Interestingly, some of the defining features in common with partnership principles and values were used across different framings of student engagement, indicating that the presence of the values themselves is not necessarily evidence of partnership. We suggest that it is how these values are applied (and who they are applied to) that distinguishes student-staff partnership from other forms of engagement. In our data, some features (like ownership and investment) were associated with students, some with the approaches staff took, and others applied to both staff and students. It is in this final section, where features are applied to both staff and students, that we feel a sense of student engagement through staff-student partnership is reflected. Issues of power and agency are crucial here.

Reflecting on ladders of student engagement (HEA \& NUS, 2011), there is often a focus on increasing levels of student agency at higher rungs. However, when we are considering staffstudent partnership, there is a call to consider how partnership values, and dimensions and features of engagement, apply to both parties. This can prompt us to consider how the affective, behavioural, and cognitive engagement of staff, and staff agency, responsibility, and ownership are enabled alongside those of students.

Published visual models of student engagement (and partnership) tend to focus on students, framing this through areas of teaching and learning practice (Healey, Flint, \& 
Harrington, 2014), student role (Bovill, Cook-Sather, Felten, Millard, \& Moore-Cherry, 2016), and spheres of student experience (Thomas, 2012). In contrast, some of our participants provided rich personal framings that were rooted in staff experience, identity, and practice. Their drawings provide valuable insight into how individuals frame their understandings and potentially offer alternative models of student engagement focused on staff perspectives to complement published models. Harris' (2008) phenomenographic study on teacher conceptions of student engagement in learning suggested that "there cannot be any 'assumed' shared knowledge about student engagement among academics or teachers" (p. 75). In terms of specific models or frameworks, our findings support this. However, our data also suggest common features that cut across different framings. It is unlikely that consensus will be reached on a single definitive approach to, or understanding of, student engagement that applies across all disciplinary, institutional, national, and international contexts. This, and the fact that some participants' understandings were emergent or previously unarticulated, argues for providing space and time for staff to reflect on, articulate, and discuss their understandings of student engagement and their role in fostering it. This process may create the possibility for common ground and approaches to be developed across diverse understandings.

Reflecting on the findings through the lens of the institutional ethos of engagement through staff-student partnerships, this may be implicit in the way some participants described how they understood and applied engagement in practice-for example, through the focus on staff-student relationships, and the features that applied to both staff and students. However, we acknowledge the small scale of this study means that this tentative alignment cannot be assumed across the university. Further research is needed to explore whether this reflects wider views.

\section{CONCLUSION}

As we started the research, there was a great deal of discussion about terminology. Researchers and participants seemed to interchange terms so that student engagement and partnerships became blurred. We questioned whether this mattered for those practising. If they were developing partnership activities with students and chose to call it student engagement, did it matter? In truth, it was something the university could not control, so there were times when the language became blurred as staff contextualised it within their own circumstances.

Our findings indicate participants' understandings shared some elements with commonly cited models of engagement and partnership, but there were also differences. We suggest that in defining student engagement, it's not what you do but how you do it: engagement is less an assemblage of specific practices and more a set of values or features that guide and shape practice. Where there is a desire to foster student-staff partnership as a form of engagement, then considering how these values and dimensions apply to both students and staff is crucial. We suggest that rather than looking for a unifying model of student engagement, we may need to embrace the plurality of models (as different ways in) and look to the values that underpin these to identify commonality and connections across diverse understandings. We encourage others to consider the use of visual methods as part of this process, enabling staff to 
individually express the complexity and messiness of their understandings of student engagement and collaboratively compare and discuss these with others as part of professional development (Flint, 2018). Our research specifically focused on staff understandings of student engagement. Given the framing of engagement as relational and the importance of staffstudent relationships, which emerged from our analysis, we tentatively suggest that the institutional ethos of student engagement through staff-student partnerships is reflected in the way some participants described engagement in practice. It would be valuable to also explore the way engagement is framed and understood by the student partners in those relationships and include students in professional development discussions.

Those of us who have been participating in this work for several years can get very precise about language and the way in which things should be delivered. For those at a different stage in that journey, it can be exciting and confusing. We ask, does it really matter what language is used as long as they demonstrate that partnership? There is a recognition across the HE sector that we live in a world of metrics, which implies we have control over all that we do. What the staff-student partnership approach at BCU has demonstrated is that sometimes it is beneficial for educational developers and others responsible for leading initiatives to let go and enable staff and students to interpret the words of partnership, collaboration, and engagement in their own way, as long as it aligns with the destination of improving the student learning experience.

Ethical approval for the research was given by the Faculty of Health, Education and Life Sciences Academic Ethics Committee at BCU.

\section{NOTES ON CONTRIBUTORS}

Dr Abbi Flint is an independent researcher and educational developer with a longstanding research and practice interest in student engagement and partnership. The research reported in this article was conducted when Abbi held a Visiting Research Fellowship in Student Engagement at BCU (2014-2017).

Luke Millard is Director of the Education Development Service at Birmingham City University. He is a strong advocate of student engagement and of co-creating the first year experience to enable student success. He is a Principal Fellow of the UK Higher Education Academy.

\section{REFERENCES}

Baxter Magolda, M. (2007). Self-authorship: The foundation for twenty-first-century education. New Directions for Teaching and Learning, 109, 69-83.

Bovill, C., Cook-Sather, A., \& Felten, P. (2011). Students as co-creators of teaching approaches, course design, and curricula: Implications for academic developers. International Journal for Academic Development, 16(2), 133-145.

Bovill, C., Cook-Sather, A., Felten, P., Millard, L., \& Moore-Cherry, N. (2016). Addressing potential challenges in co-creating learning and teaching: Overcoming resistance,

Flint, A., \& Millard, L. (2018). "Interactions with purpose": Exploring staff understandings of student 35 engagement in a university with an ethos of staff-student partnership. International Journal for 
navigating institutional norms and ensuring inclusivity in student-staff partnerships. Higher Education, 71(2), 195-208.

Bryson, C., \& Hardy, C. (2012). The nature of academic engagement: What the students tell us. In I. Solomonides, A. Reid, \& P. Petocz (Eds.). Engaging with learning in higher education (pp. 25-46) Faringdon: Libri.

Chickering, A., \& Reisser, L. (1993). Education and identity. San Francisco: Jossey-Bass Cohen, L., Manion, L., \& Morrison, K. (2011). Research methods in education (7th ed.). London, Routledge.

Cook-Sather, A. (2013). Student-faculty partnership in explorations of pedagogical practice: A threshold concept in academic development. International Journal for Academic Development, 19(3), 186-198

Cook-Sather, A., Bovill, C., \& Felten, P. (2014). Engaging students as partners in learning and teaching. San Francisco, CA: Jossey-Bass.

Curran, R., \& Millard, L. (2015). A partnership approach to developing student capacity to engage and staff capacity to be engaging: Opportunities for academic developers. International Journal for Academic Development, 21(1), 67-78.

Department for Education. (2017). Teaching excellence and student outcomes framework specification. Retrieved from https://www.gov.uk/government/publications/teachingexcellence-and-student-outcomes-framework-specification

Fielding, M. (2004). Transformative approaches to student voice: Theoretical underpinnings, recalcitrant realities. British Educational Research Journal, 30(2), 295-311.

Flint, A. (2016). Moving from the fringe to the mainstream: Opportunities for embedding student engagement through partnership. Student Engagement in Higher Education Journal, 1(1). Retrieved from https://journals.gre.ac.uk/index.php/raise/issue/view/46/showToc

Flint, A. (2018). Un-fuzzing the fuzzword: Reflections on using visual methods to explore understandings of student engagement through partnership in 'Proceedings of the RAISE international colloquium on partnership'. Student Engagement in Higher Education Journal, 2(1), 116-117. Retrieved from https://journals.gre.ac.uk/index.php/raise/article/view/Bryson

Fredricks, J., Blumenfeld, P., \& Paris, A. (2004). School engagement: Potential of the concept, state of the evidence. Review of Educational Research, 74(1), 59-109.

Gibbs, G. (2016). \#53Ideas 42-'Student engagement' is a slippery concept. The SEDA Blog. Retrieved from http://thesedablog.wordpress.com/2016/01/27/53ideas-42/\#more-496

Gourlay, L. (2017). Student engagement, 'learnification' and the socio-material: Critical perspectives on higher education policy. Higher Education Policy, 30(1), 23-34.

Harris, L. (2008). A phenomenographic investigation of teacher conceptions of student engagement in learning. The Australian Educational Researcher, 35(1), 57-79.

HEA (2016) FrameWORKS. 04 student engagement through partnership. Higher Education Academy, York.

Flint, A., \& Millard, L. (2018). "Interactions with purpose": Exploring staff understandings of student 36 engagement in a university with an ethos of staff-student partnership. International Journal for 
HEA \& NUS (2011). Student engagement toolkit. Retrieved from https://www.nusconnect.org.uk/the-student-engagement-partnership-tsep/studentengagement-toolkit

Healey, M., Flint, A., \& Harrington, K. (2014). Engagement through partnership: Students as partners in learning and teaching in higher education. Retrieved from https://www.heacademy.ac.uk/knowledge-hub/engagement-through-partnershipstudents-partners-learning-and-teaching-higher

Hodge, D., Baxter Magolda, M., \& Haynes, C. (2009, Fall). Engaged learning: Enabling selfauthorship and effective practice. Liberal Education, 95(4), 16-23.

Jewitt, C., \& Oyama, R. (2001). Visual meaning: A social semiotic approach. In T. van Leewen \& C. Jewitt (Eds.). The handbook of visual analysis (pp. 134-156). London: Sage.

Kahn, P. (2014). Theorising student engagement in higher education. British Educational Research Journal, 40(6), 1005-1018.

Kahu, E. (2013). Framing student engagement in higher education. Studies in Higher Education, 38(5), 758-773.

Kahu, E., Picton, C., \& Nelson, K. (2017, July). Experiencing the educational interface: Understanding student engagement. Poster presentation, STARS Conference, Adelaide, Australia.

Kandiko, C., \& Mawer, M. (2013). Student expectations and perceptions of higher education. Retrieved from https://www.kcl.ac.uk/study/learningteaching/kli/People/Research/studentexpectations-perceptions-HE.aspx

Kinchin, I., Streatfield, D., \& Hay, D. (2010). Using concept mapping to enhance the research interview. International Journal of Qualitative Methods, 9(1), 52-68.

Kuh, G. (2008). High-impact educational practices: What they are, who has access to them, and why they matter. Washington DC: AAC\&U.

Kress, G., \& van Leeuwen, T. (1996). Reading images: The grammar of visual design. London: Routledge.

Macfarlane, B. \& Tomlinson, M. (2017). Critiques of student engagement. Higher Education Policy, 30(1), 5-21.

Mercer-Mapstone, L., Dvorakova, S., Matthews, K. E., Abbot, S., Cheng, B., Felten, P., Knorr, K., Marquis, E., Shammas, R., \& Swaim, K. (2017). A systematic literature review of students as partners in higher education. International Journal for Students as Partners, 1(1). Retrieved from https://doi.org/10.15173/ijsap.v1i1.3119

Mitchell, C., Theron, L., Stuart, J., Smith, A., \& Campbell, Z. (2011). Drawings as research method. In L. Theron, C. Mitchell, A. Smith, \& J. Stuart (Eds.). Picturing research: Drawing as visual methodology (pp 19-36). Rotterdam: Sense Publishers.

Neary, M. (2012). Student as producer: An institution of the common? [or how to recover communist/revolutionary science]. York: Higher Education Academy. Retrieved from http://studentasproducer.lincoln.ac.uk/files/2014/03/ELiSS0403A Guest paper.pdf 
Newbery, G. (2012). The psychology of being engaged and its implications for promoting engagement. In I. Solominides, A. Reid, \& P. Petocz, (Eds.). Engaging with learning in higher education (pp. 47-70). Faringdon: Libri.

Nygaard, C., Brand, S., Bartholomew, P., \& Millard, L. (Eds.). (2013). Student engagement: Identity, motivation and community. Faringdon: Libri.

Quality Assurance Agency. (2012). UK quality code for higher education-Chapter B5: Student engagement. Retrieved from https://www.qaa.ac.uk/quality-code/the-existing-ukquality-code/part-b-assuring-and-enhancing-academic-quality

Solomonides, I., Reid, A., \& Petocz, P. (2012). A relational model of student engagement. In I. Solomonides, A. Reid, \& P. Petocz, (Eds.). Engaging with learning in higher education (pp. 11-24). Faringdon: Libri.

Thomas, L. (2012) Building student engagement and belonging in higher education at a time of change: Final report from the What Works? Student Retention and Success programme. Retrieved from https://www.heacademy.ac.uk/knowledge-hub/building-studentengagement-and-belonging-higher-education-time-change-final-report

Trowler, P., \& Trowler, V. (2010). Student engagement evidence summary. Retrieved from http://eprints.lancs.ac.uk/61680/1/Deliverable 2. Evidence Summary. Nov 2010.pdf

Trowler, V. (2010). Student engagement literature review. Retrieved from https://www.heacademy.ac.uk/system/files/StudentEngagementLiteratureReview 1.pd f

Vuori, J. (2014). Student engagement: Buzzword or fuzzword? Journal of Higher Education Policy and Management, 36(5), 509-519.

Wenstone, R. (2012). A manifesto for partnership. Retrieved from http://www.nusconnect.org.uk/resources/a-manifesto-for-partnership

Werder, C., \& Otis, M. (Eds.) (2010). Engaging student voices in the study of teaching and learning. Sterling, VA: Stylus.

Wheeldon, J., \& Faubert, J. (2009). Framing experience: Concept maps, mind maps, and data collection in qualitative research. International Journal of Qualitative Methods, 8(3), 6883.

Wimpenny, K., \& Savin-Baden, M. (2013). Alienation, agency and authenticity: A synthesis of the literature on student engagement. Teaching in Higher Education, 18(3), 311-326. 